\title{
A catalogue of reptiles of Monfragüe National Park (Spain), with molecular characterization of populations of Blanus Wagler, 1830 in this protected area
}

\author{
Daniel Fernández-Ortín¹, Gregorio Sánchez-Montes², Íñigo Martínez-Solano,** \\ ${ }^{1}$ Betania, 1, bajo G, 10003 Cáceres, Spain. \\ ${ }^{2}$ Departamento de Biodiversidad y Biología Evolutiva, Museo Nacional de Ciencias Naturales, José Gutiér- \\ rez Abascal, 2, 28006 Madrid, Spain. \\ *Correspondence: E-mail: inigomsolano@mnc.csic.es
}

Received: 17 July 2019; returned for review: 29 October 2019; accepted 06 November 2017.

\begin{abstract}
Monfragüe National Park (Cáceres, Extremadura, Spain) is a protected area in central-western Iberia,including some of the best preserved primary Mediterranean vegetation. Legal protection dates back to 1979 (first as a Natural Park and then as a National Park), but knowledge about its reptile communities is so far limited to sparse records. In this paper we present an updated species list based on 521 records covering $1631 \times 1 \mathrm{~km}$ UTM grids in the study area, compiled in the period 2000-2019. We detected 20 native species, representing 71.4\% of the reptile fauna in Extremadura and $35 \%$ of the ibero-balearic reptile fauna. Additionally, based on molecular analyses populations of the amphisbaenid genus Blanus in the study area are assigned to the oriental Iberian taxon, $B$. cinereus. The new records extend the known distribution of the different reptile species in the study area in 56 10x10 km UTM grids. Species presenting more restricted distributions in Monfragüe are Lacerta schreiberi (one 1x1 grid), Emys orbicularis, and Acanthodactylus erythrurus (four 10x10 grids each).
\end{abstract}

Key words: Blanus cinereus; Extremadura; Iberian Peninsula; Monfragüe National Park; reptiles.

The Iberian Peninsula hosts a great diversity of habitats and ecosystems, a legacy of its deep geological history and topographic complexity. National parks provide legal protection for representative natural areas including singular geological characteristics, flora, and fauna. Monfragüe National Park is located in the province of Cáceres, in the region of Extremadura, in central-western Iberia, occupying an extension of 18396 ha of rugged terrain with steep slopes, and includes some of the best preserved primary Mediterranean vegetation. The National Park and its Pe- ripheral Protected Area ("Zona Periférica de Protección", ZPP) conform a study area of 116000 ha (Fig. 1), which includes other protected areas like ZEPA "ES0000014 Monfragüe y las Dehesas del Entorno", ZEC “ES4320077 Monfragüe” and a Biosphere Reserve.

Monfragüe National Park has been legally protected since 1979 (first as a Natural Park and since 2007 as a National Park), but there is little information about its reptile communities. Apart from the study of Álvarez-VAsserot (1998), the information about the reptile fauna of 


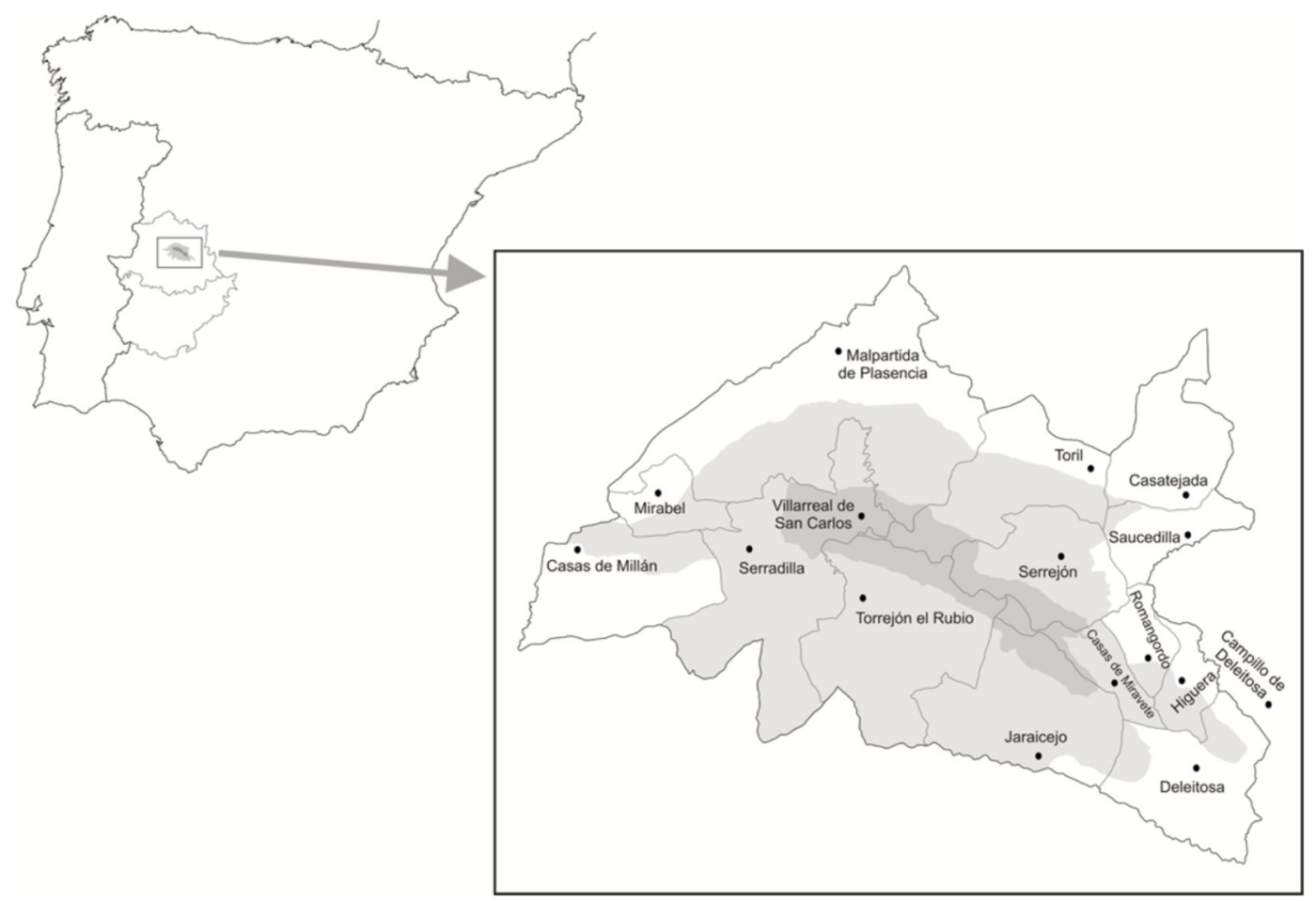

Figure 1: Location of the study area.

Monfragüe consists of sparse records, with the exception of a survey conducted by biology students from the University of Extremadura (Muñoz deL VIEjo, 2005). The poor knowledge about reptiles in Monfragüe is in line with the situation in most of the 15 national parks in Spain (16 in Iberia considering Peneda Gerês National Park in Portugal). Of all these protected areas, there are only detailed studies and species catalogues in the national parks of Islas Atlánticas (Galán Regalado, 2003), Peneda Gerês (Soares et AL., 2005), Picos de Europa (Ayllón et Al., 2010), and Doñana (ANDReu, 2014). In other national parks like Cabañeros, Sierra de Guadarrama and Sierra Nevada there are monitoring programs of herptile populations, but mostly focusing on amphibians. Other information about reptiles in national parks comprises specific reports on conservation plans for threatened species in the Canary islands or isolated records, like the first report of the presence of Lacerta schreiberi Bedriaga, 1878 in Monfragüe (FernándezOrtín \& Toboso-Borrella, 2014).

Of all reptile taxa present in Monfragüe National Park, genus Blanus WAgLer, 1830 is the only case presenting a conflict regarding specific characterization of its populations. At present, two lineages are known to occur in Iberia: an occidental lineage, in the Iberian southwest, and an oriental one distributed across the rest of Iberia. In 2009, Albert \& Fernández described a new blanid species in Iberia, 
Blanus mariae Albert \& Fernández, 2009. Its distribution encompasses the southwestern quadrant of Iberia, thus representing the occidental lineage, with its northern range border in the province of Cáceres (Albert \& Fernández, 2009). Albert et $A L$. (2007) identified the closest Blanus records to Monfragüe as Blanus cinereus VANDELLI, 1797, at the southern Tajo river margin, in the locality of Garciaz in Cáceres. Nevertheless, Sampaio et al. (2014) recorded the presence of $B$. mariae north of the Tajo river, in the portuguese locality of Carvalhão, suggesting that the two species of Iberian Blanus could coexist in the vicinities of Monfragüe National Park, since both lineages occupy both the northern and southern margins of the Tajo river.

Based on alleged nomenclatural problems in Albert \& Fernández's (2009) description of B. mariae, Ceríaco \& BaUer (2018) concluded that B. mariae is a junior synonym of $B$. cinereus and described Blanus vandellii CERÍACO \& BAUER, 2018 as a new species. Thus, according to these authors, all $B$. cinereus records should be ascribed to the new species, $B$. vandellii, and $B$. mariae records should be assigned to $B$. cinereus. However, the existence of another problematic taxon, B. rufus (Hemprich, 1820), with type locality in "southern Spain", an area where the two Iberian lineages co-occur, suggests that the new species, $B$. vandellii, could be likewise considered a junior synonym of $B$. rufus. This circumstance will not be resolved until the type specimen of B. rufus can be assigned to either the occidental or the oriental Iberian Blanus lineage.

In the current study, we present an updated reptile species catalogue for Monfra- güe National Park, and new molecular evidence regarding the specific status of Blanus populations in this protected area. We provide $>500$ new records documenting the presence of 20 native reptile species in Monfragüe, and show the presence of $B$. cinereus in two localities in the study area based on the analysis of sequences of the mitochondrial DNA gene ND4.

\section{Materials and Methods}

This study is based on a compilation of observations of reptiles from surveys conducted between 2000 and June 2019, documented in a database including photographic records. These records were obtained through direct observation, photographs, and, occasionally, identification in hand. No individual was sacrificed for identification or tissue sampling.

The study area includes Monfragüe National Park and its ZPP; as geographic reference we used the system UTM_MGRS ED50, zones $29 \mathrm{~N}$ and 30N, codes EPSG: 23029 and 23030, and referenced observations in 1x1 km UTM grids. For georeferencing, we used cartographic viewers ("Sistema de Información Geográfica de Parcelas Agrícolas del Ministerio de Agricultura y Pesca, Alimentación y Medio Ambiente, SIGPAC" (Mapa.gob.es, s.f.), and "Instituto Geográfico Nacional, IBERPIX" (Instituto Geográfico Nacional de España, s.f.). Toponyms were obtained from 1:25 000 maps in both cartographic servers or from local denominations.

The orography of Monfragüe is defined by two major mountain chains running in parallel NW-SE, with the highest peaks at Pico de Miravete (839 m a.s.l.) and Sierra de Enmedio (870 m a.s.l.), in Casas de 


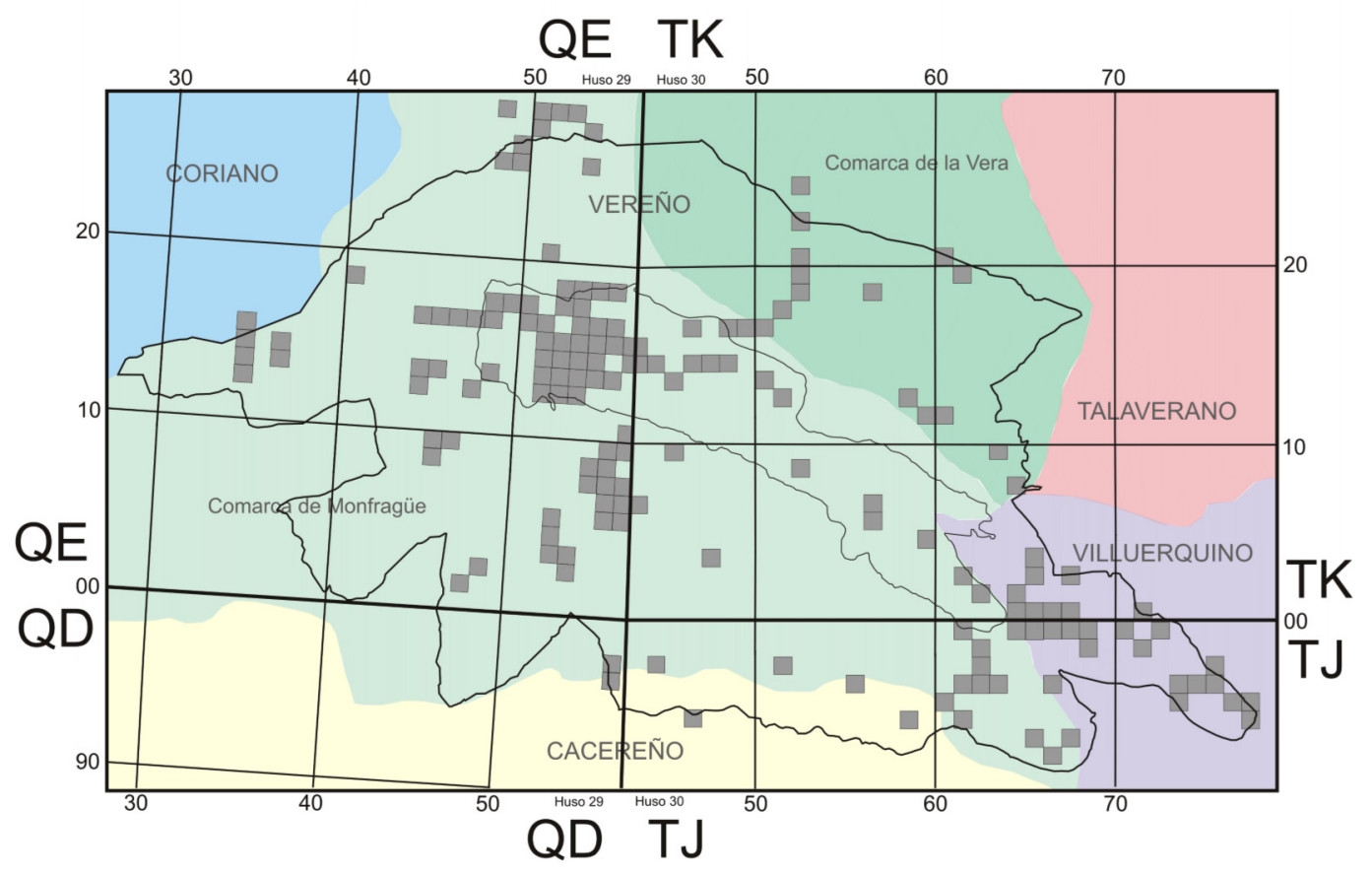

Figure 2: Sampling effort (grey squares) and biogeographic regions in the study area, showing $10 \times 10$ km UTM grids.

Miravete and Deleitosa, respectively. Nevertheless, most of the study area comprises elevations ranging from $220 \mathrm{~m}$ to $600 \mathrm{~m}$. The two most prominent hydrographic features are rivers Tajo and Tiétar, embedded in steep margins and dammed along their full course in the study area. The hydrological network in Monfragüe is complemented with second order streams associated with these two major river basins; most of them are temporary, with higher water flow in the spring, and low flow during the drier months. The water table only surfaces at fountains and springs, with no relevant endorreic ponds except Laguna de Cantalgallo, in Jaraicejo, and Lagunas de Mesas Caveras, in Deleitosa.

According to Belmonte López (2008) Monfragüe National Park and its ZPP are part of the Western Iberian Mediterranean biogeographic province, "LusoExtremadurense" subprovince, "ToledanoTagano" sector, and include five districts: "Talaverano", "Vereño" and "Coriano", in the "Talaverano-Placentino" subsector; and "Cacereño" and "Villuerquino", in the "Oretano" subsector (Fig. 2). Average annual rainfall ranges from $868 \mathrm{~mm}$ in Malpartida de Plasencia to $551 \mathrm{~mm}$ in Torrejón el Rubio. Most of the study area presents climatic values associated with the Oceanic Pluvistational Mediterranean bioclimate, except the southeastern part, where climatic data from the station at Campillo de Deleitosa (Fig. 1) provides values within the Continental Pluvistational Mediterranean type. Regarding thermal and ombrotypes, almost all the study area is with- 
in the Mesomediterranean ("Inferior-SecoSuperior") realm, except some spots at the southeastern border, which present characteristics within the Mesomediterranean ("Superior-Subhúmedo-Inferior") realm. With respect to temperatures, the station of Campillo de Deleitosa is singular, with periods of freezing every year, but average annual temperatures in the study area range from $18^{\circ} \mathrm{C}$ in Torrejón el Rubio to $15^{\circ} \mathrm{C}$ in Campillo de Deleitosa.

We used specific methodologies to locate different species all year round, like nocturnal surveys for Tarentola mauritanica Linnaeus, 1758 and Hemidactylus turcicus (Linnaeus, 1758), or inspecting rocks and other refugia, which was useful to locate fossorial species like $B$. cinereus. We also recorded road-killed individuals during road surveys. When planning these prospections, we took into consideration the environmental requirements of target species, and the bioclimatic characteristics of different parts of the study area. For instance, Lacerta schreiberi requires especially humid areas, and thus sampling sites were selected using other taxa as bioindicators, like the Iberian frog Rana iberica Boulenger, 1879 or the trees Alnus glutinosa (L.) Gaertn. and Prunus lusitanica L., which are typical from humid bioclimates. Prospected $1 \times 1 \mathrm{~km}$ grids were selected based on their accessibility and the presence of favourable habitats for reptiles. We did not perform systematic surveys, but many sites have been visited often. Thus, we acknowledge that many species records correspond to chance observations.

Systematic treatment of the species follows the most recent taxonomic recom- mendations of Asociación Herpetológica Española (CARretero et AL., 2018). Thus, regarding genus Blanus, we follow their decision to accept B. mariae as a valid taxon, with $B$. cinereus representing the oriental lineage in Iberia. For estimates of ibero-balearic species richness we excluded allochthonous taxa and marine species. Observations recorded during field surveys were contrasted with literature records (Pleguezzuelos et Al., 2002), and the database of amphibian and reptile records maintained by Asociación Herpetológica Española (S.I.A.R.E., s.f.). Biogeographic classification of species follows SaLvador Milla (2002).

For the molecular characterization of samples of Blanus in Monfragüe we analysed sequences of a fragment of mitochondrial gene ND4 and adjacent tRNAs in two individuals collected in Torrejón el Rubio (accession code, Tissue and DNA collection, Museo Nacional de Ciencias Naturales: MNCN:ADN: 94916), and Casas de Miravete (accession code: MNCN:ADN: 94917) (see location in the study area in Supplementary Material). We extracted DNA from tissue samples stored in ethanol with a commercial kit (QIAquick, QIAGEN, Germany). Then, we amplified the target fragment via polymerase chain reaction (PCR) with primers ND4 and LEU (ARÉvalo et Al., 1994), following the conditions described in Albert ET AL. (2007), with minor modifications. Amplified products were sequenced in both directions with PCR primers and sequences were assembled and edited with software Sequencher (Gene Codes, USA). New sequences were compared with those available in GenBank (https:// 
www.ncbi.nlm.nih.gov/genbank/) using the BLAST algorithm (https:// blast.ncbi.nlm.nih.gov/Blast.cgi), which identifies the most similar sequences in the database.

\section{Results}

Based on our fieldwork we compiled a database with 521 records in $1631 \times 1 \mathrm{~km}$ UTM grids, $12.4 \%$ of the study area (Fig. 2), and detected 20 native species (Table 1 , see maps in Supplementary Material), representing $71.4 \%$ of the reptile species in Extremadura and $35 \%$ of the ibero-balearic reptile fauna. These records expand our knowledge of the distribution of reptiles in Monfragüe in 55 new 10x10 km UTM grids (see maps in Supplementary Material). In addition, in 2004 we found an adult individual of the alien, invasive species Trachemys scripta elegans (WIED, 1838), but it was not seen again in subsequent years.

There are eight reptile species in Extremadura that have not been reported to occur in Monfragüe, and did not appear in our surveys (Table 2). Two of them have been reported in localities close to the study area: Hemidactylus turcicus and Podarcis guadarramae (Boscá, 1916), which could therefore be present in Monfragüe. Hemidactylus turcicus has been reported in Cañaveral (S.I.A.R.E., s.f.), near the western limit of the study area, whereas there is a small, isolated population of $P . g u a-$ darramae in Trujillo (Geniez eT AL., 2014), south of the study area.

We obtained two sequences of 848 base pairs for the two individuals of Blanus analysed (GenBank accession numbers: MK978773-MK978774). Comparison of these sequences with those available in
GenBank showed similarity scores $\geq$ 94.75\% with sequences of Blanus cinereus, and $\leq 89.1 \%$ with Blanus mariae, confirming the presence of the former species in Monfragüe National Park in the two studied localities.

\section{Discussion}

We found all the species previously cited in Monfragüe, representing nine out of the 13 reptile families present in the Iberian Peninsula and the Balearic Islands. Of the 11 reptile families present in Extremadura, only Anguidae and Gekkonidae are missing. Families Testudinidae and Chamaeleonidae, absent in Extremadura, are not present in Monfragüe either.

Of all reptile families present in Monfragüe, Lacertidae has the lowest representation of its ibero-balearic diversity, with just $20 \%$ of species present in the study area. This is probably related with the low altitudinal range in Monfragüe, with altitudes mostly between 220 and $600 \mathrm{~m}$ a.s.l. This can explain the absence of species with strict orophylous requirements, like genus Iberolacerta Arribas, 1997, which is characterized by high taxonomic diversity. Likewise, another taxonomically diverse but poorly represented genus in Monfragüe is Podarcis WAgLer, 1830, with a single representative, Podarcis virescens GEniez, Sá-Sousa, Guillaume, Cluuchier \& CRochet, 2014. The most likely reason is also the lack of ecological heterogeneity, in addition to the phylogenetic characteristics of the group, formed by cryptic species with parapatric distributions (GENIEZ ET AL., 2007; Kaliontzopoulou et AL., 2012).

The faunistic composition of the reptile communities of Monfragüe is strictly Med- 
Table 1: Taxonomic diversity of reptiles in Monfragüe National Park. Sp = number of species in Monfragüe, $\mathrm{P}^{1}=$ proportion of species with respect to Extremadura and $\mathrm{P}^{2}=$ proportion of species with respect to the Iberian Peninsula and the Balearic Islands, $1 \times 1=$ number of $1 \times 1 \mathrm{~km}$ UTM grids where the species was found in this work, 10x10 = number of 10x10 km UTM grids with records for the species, Distr. $=$ distribution, $\mathrm{Pal}=$ Palearctic, $\mathrm{Med}=$ Mediterranean, End $=\mathrm{Iberian}$ endemic.

\begin{tabular}{|c|c|c|c|c|c|}
\hline Order & Family & Species & $1 \times 1$ & $10 \times 10$ & Distr. \\
\hline \multirow{2}{*}{$\begin{array}{l}\text { CHELONII } \\
\text { Sp: } 2 \\
\mathrm{P}^{1}: 100 \% \\
\mathrm{P}^{2}: 50 \%\end{array}$} & $\begin{array}{l}\text { Emydidae } \\
\text { Sp: } 1 ; \mathrm{P}^{1}: 100 \% ; \mathrm{P}^{2}: 100 \%\end{array}$ & Emys orbicularis & 4 & 4 & Pal \\
\hline & $\begin{array}{l}\text { Geoemydidae } \\
\text { Sp: } 1 ; \mathrm{P}^{1}: 100 \% ; \mathrm{P}^{2}: 100 \%\end{array}$ & Mauremys leprosa & 23 & 23 & Med \\
\hline \multirow{18}{*}{$\begin{array}{l}\text { SQUAMATA } \\
\text { Sp: } 18 \\
\mathrm{P}^{1}: 69,2 \% \\
\mathrm{P}^{2}: 34 \%\end{array}$} & $\begin{array}{l}\text { Phyllodactylidae } \\
\text { Sp: } 1 ; P^{1}: 100 \% ; P^{2}: 100 \%\end{array}$ & Tarentola mauritanica & 23 & 17 & Med \\
\hline & Scincidae & Chalcides bedriagai & 4 & 5 & End \\
\hline & Sp: 2; P1:100\%; P2:100\% & Chalcides striatus & 20 & 10 & Med \\
\hline & \multirow{6}{*}{$\begin{array}{l}\text { Lacertidae } \\
\text { Sp: 6; } \mathrm{P}^{1}: 60 \% ; \mathrm{P}^{2}: 20 \%\end{array}$} & $\begin{array}{l}\text { Acanthodactylus } \\
\text { erythrurus }\end{array}$ & 1 & 4 & Med \\
\hline & & Lacerta schreiberi & 1 & 1 & End \\
\hline & & Podarcis virescens & 27 & 12 & End \\
\hline & & $\begin{array}{l}\text { Psammodromus } \\
\text { algirus }\end{array}$ & 59 & 23 & Med \\
\hline & & $\begin{array}{l}\text { Psammodromus } \\
\text { occidentalis }\end{array}$ & 12 & 9 & End \\
\hline & & Timon lepidus & 56 & 24 & Med \\
\hline & $\begin{array}{l}\text { Blanidae } \\
\text { Sp: } 1 ; \mathrm{P}^{1}: 50 \% ; \mathrm{P}^{2}: 50 \%\end{array}$ & Blanus cinereus & 18 & 16 & End \\
\hline & \multirow{6}{*}{$\begin{array}{l}\text { Colubridae } \\
\text { Sp: 6; P1:85.7\%; } \\
\text { P2:54.5\% }^{2} \text {; }\end{array}$} & $\begin{array}{l}\text { Hemorrhois } \\
\text { hippocrepis }\end{array}$ & 18 & 13 & Med \\
\hline & & Zamenis scalaris & 18 & 15 & Med \\
\hline & & Coronella girondica & 12 & 11 & Med \\
\hline & & Macroprotodon brevis & 12 & 9 & Med \\
\hline & & Natrix maura & 27 & 23 & Med \\
\hline & & Natrix astreptophora & 8 & 8 & Med \\
\hline & $\begin{array}{l}\text { Lamprophiidae } \\
\text { Sp: 1; } P^{1}: 100 \% ; P^{2}: 100 \%\end{array}$ & $\begin{array}{l}\text { Malpolon } \\
\text { monspessulanus }\end{array}$ & 24 & 18 & Med \\
\hline & $\begin{array}{l}\text { Viperidae } \\
\text { Sp: } 1 ; \mathrm{P}^{1}: 100 \% \\
\mathrm{P}^{2}: 33.3 \%\end{array}$ & Vipera latastei & 7 & 6 & Med \\
\hline
\end{tabular}


Table 2: Taxonomic diversity of species present in Extremadura but not found in the study area. Distr. $=$ distribution, EurSib $=$ Eurosiberian, $\mathrm{Med}=$ Mediterranean, End $=$ Iberian endemic.

\begin{tabular}{llll}
\hline Order & Family & Species & Distr. \\
\hline \multirow{2}{*}{ Blanidae } & Blanus mariae Albert \& Fernández, 2009 & End \\
\cline { 2 - 4 } & Anguidae & Anguis fragilis Linnaeus, 1758 & EurSib \\
\cline { 2 - 4 } & Gekkonidae & Hemidactylus turcicus (Linnaeus, 1758) & Med \\
\cline { 2 - 4 } & & Iberolacerta cyreni (Müller \& Hellmich, 1937) & End \\
& Lacertidae & Podarcis guadarramae (Boscá, 1916) & End \\
& & Podarcis carbonelli Pérez-Mellado, 1981 & End \\
\cline { 2 - 4 } & Colubridae & Coronella austriaca Laurenti, 1768 & EurSib \\
\hline
\end{tabular}

iterranean, with a single taxon exhibiting a wider chorology: Emys orbicularis (Linnaeus, 1758), with a Palearctic distribution. Families Colubridae and Viperidae clearly illustrate this affinity of reptiles in Monfragüe for thermal environments, since only species with a Mediterranean distribution in these families are present in Monfragüe: Hemorrhois hippocrepis (LinnaEus, 1758), Zamenis scalaris (Schinz, 1822), Coronella girondica (DAUdin, 1803), Macroprotodon brevis (Günther, 1862), Natrix maura (Linnaeus, 1758), and Natrix astreptophora (LópezSeOANe, 1884) among Colubridae, and Vipera latastei Boscá, 1878 in Viperidae.

Families most represented in Monfragüe are typically Mediterranean and with few elements in the ibero-balearic context. This is the case of Emydidae, with a single representative, E. orbicularis; Geoemydidae, with one representative, Mauremys leprosa (Schweigger, 1812); Phyllodactylidae, with one representative, Tarentola mauritanica; Scincidae, with two representatives,
Chalcides bedriagai (Boscá, 1880), and Ch. striatus (Cuvier, 1829); and Lamprophiidae, with one representative, Malpolon monspessulanus (HermanN, 1804), all of which have $100 \%$ representation in Monfragüe.

With just five species, the endemic reptile fauna of Monfragüe is below levels of endemism in Extremadura and the iberobalearic fauna: 25\% endemisms in Monfragüe compared to $35.7 \%$ in Extremadura, and $33.33 \%$ in Iberia and the Balearic Islands. This is probably a result of the absence of genus Iberolacerta and the low representation of genus Podarcis in Monfragüe, since both genera include a high number of endemic taxa.

Taxonomically complex species in the study area include: $B$. cinereus, $P$. virescens and Psammodromus occidentalis FITZE, González-Jimena, San-José, San Mauro \& ZARDoya, 2012. The presence of B. cinereus in Monfragüe has been confirmed with mtDNA sequences in this study. Regarding Podarcis, Geniez et AL. (2014) cite a 
subadult individual of $P$. virescens in arroyo de La Vid in Torrejón el Rubio, within the ZPP of the National Park. Finally, Fitze ET AL. (2012) record P. occidentalis in Aldea del Obispo, just a few km from the southern limit of the ZPP. Species of these three genera (Blanus, Podarcis and Psammodromus) generally have parapatric distributions, and therefore, all records in the study area could in principle be assigned to the referred taxa. However, some published records of $B$. mariae and $P$. guadarramae are close to Monfragüe, so it's not unlikely that these species will be reported within the limits of the National Park in future studies.

According to the maps presented in the Supplementary Material, the most widespread species in the study area are Timon lepidus (DAudin, 1802), recorded in 24 of the $2510 \times 10$ UTM grids in Monfragüe, M. leprosa, P. algirus (Linnaeus, 1758), and N. maura (23 grids each). On the contrary, the species with a more restricted distribution in Monfragüe are $L$. schreiberi, found in a single $1 \times 1 \mathrm{~km}$ UTM grid, E. orbicularis, and Acanthodactylus erythrurus (ScHinz, 1833), in four 10x10 km UTM grids each.

Of all reptile species in Monfragüe, $L$. schreiberi is the most threatened (FERNÁNDEZOrtín \& Toboso-Borrella, 2014). In Iberia, Marco \& Pollo (1993) associate the presence of the species with the Eurosiberian and Mediterranean biogeographic regions, with $95,6 \%$ of the species records in the Supra- and Oromediterranean bioclimatic regions. The Mesomediterranean region, characteristic in most of Monfragüe, only accounts for $4.42 \%$ of the species records. Environmental characteris- tics of the single locality for L. schreiberi in Monfragüe were described in Fernández-Ortín \& Toboso-Borrella, 2014. We visited the area often, with new observations in dates: 25/06/14, 16/04/17, 23/06/17 and 15/07/17, all in the same site.

The new information presented in this study can inform conservation actions for reptiles in Monfragüe, especially for species presenting relict populations in the area. Future studies should include systematic surveys in order to detect the potential presence of additional species, and set the basis for a long-term monitoring of some of the best examples of reptile communities in Mediterranean areas.

\section{Acknowledgement}

We thank X. Santos and an anonymous reviewer for constructive comments. José María Benítez, Ángel Blázquez, Óscar Díaz, Adrián Fernández, Inés García, José María Jiménez and Francisco Pérez provided data or helped in field surveys. Special thanks to Pedro Holgado for sharing some records of Vipera latastei. Isabel Rey and Beatriz Álvarez of the Tissue and DNA collection at Museo Nacional de Ciencias Naturales facilitated access to samples and molecular analyses. Finally, we thank managers of Monfragüe National Park and park rangers the facilities provided to conduct field work.

\section{References}

Albert, E., Zardoya, R. \& García-París, M. (2007). Phylogeographical and speciation patterns in subterranean worm lizards of the genus Blanus (Amphisbaenia: Blanidae). Molecular Ecology 16(7): 1519-1531.

Albert, E. \& Fernández, A. (2009). Evidence of cryptic speciation in a fossorial reptile: 
description of a new species of Blanus (Squamata: Amphisbaenia: Blanidae) from the Iberian Peninsula. Zootaxa 2234: 56-68.

Álvarez-Vasserot, J.L. (1998). Áreas naturales de Extremadura (Parque Natural de Monfragüe, Valencia de Alcántara y alrededores del río Tamuja), In X. SAntos, M.A. Carretero, G.A. Llorente \& A. Montori (eds.) Inventario de las Áreas Importantes para los Anfibios y Reptiles de España. Ministerio de Medio Ambiente. Madrid, Spain, pp. 155160.

Andreu, A.C. (2014). Seguimiento de anfibios y reptiles en Doñana. Boletín de la Asociación Herpetológica Española 25(2): 65-75.

Arévalo, E., Davis, S.K. \& Sites, J.W. Jr (1994). Mitochondrial DNA sequence and phylogenetic relationships among eight chromosome races of the Sceloporus grammicus complex (Phrynosomatidae) in central México. Systematic Biology 43: 387-418.

Ayllón, E., Bosch, J., Diego-Rasilla, F.J., HerNÁNDEZ, P.L., MorA, A. \& RodríguezGarcía, L. (2010). Anfibios y reptiles del Parque Nacional de los Picos de Europa. Organismo Autónomo de Parques Nacionales. MIMARM. Madrid, Spain, pp. 211.

Belmonte López, M.D. (2008). La vegetación del Monfragüe. Parque Nacional. Cáceres. España. www.extremambiente.es. Consejería de Agricultura, Desarrollo Rural, Medio Ambiente y Energía. Gobierno de Extremadura. http://extremambiente.juntaex.es/files/ biblioteca_digital/

La_Vegetacion_de_Monfrague.pdf. [Accessed: April 7 2019], pp. 768.

Carretero, M.A., Martínez-Solano, I., AyLLón, E. \& Llorente, G. (2018). Lista patrón de los anfibios y reptiles de España / diciembre 2018. Asociación Herpetológica Española, Madrid, Spain, pp. 83.

Ceríaco, L.M.P. \& Bauer, A.M. (2018). An integrative approach to the nomenclature and taxonomic status of the genus Blanus Wagler, 1830 (Squamata: Blanidae) from the Iberian Peninsula. Journal of Natural History 52: 849-880.

Fernández-Ortín, D. \& Toboso-Borrella, A. (2014). Lacerta schreiberi, nueva especie de reptil para la Zona Periférica de Protección del Parque Nacional de Monfragüe (Cáceres, España). Boletín de la Asociación Herpetológica Española 25(1): 51-54.

Fitze, P.S., González-Jimena, V., San José, L.M., San Mauro, D. \& Zardoya, R. (2012). A new species of sand racer, Psammodromus (Squamata: Lacertidae), from the Western Iberian Peninsula. Zootaxa 3205: 41-52.

Galán Regalado, P. (2003). Anfibios y reptiles del Parque Nacional de las Islas Atlánticas de Galicia. Faunística, biología y conservación. Organismo Autónomo de Parques Nacionales, MIMARM, Madrid, Spain, pp. 276.

Geniez, P., Cluchier, A., SÁ-Sousa, P., Guillaume, C.P. \& Crochet, P.A. (2007). Systematics of the Podarcis hispanicus complex (Sauria, Lacertidae) I: Redefinition, morphology and distribution of the nominotypical taxon. Herpetological Journal 17: 69 -80 .

Geniez, P., Sá-Sousa, P., Guillaume, C. P., Cluchier, A. \& Crochet, P. A. (2014). Systematics of the Podarcis hispanicus complex (Sauria, Lacertidae) III: valid nomina of the western and central Iberian forms. Zootaxa 3794(1): 1-51.

Instituto Geográfico Nacional de España. s.f. Visor IBERPIX. Ministerio de Fomento, Madrid. http://contenido.ign.es/iberpix2/ visor/ [Accessed: April 7 2019].

Kaliontzopoulou, A., Carretero, M.A., LloRENTE, G.A. (2012). Morphology of the Podarcis wall lizards (Squamata: Lacertidae) from the Iberian Peninsula and North Africa: patterns of variation in a putative cryptic species complex. Zoological Journal of the Linnean Society 164: 173-193.

Mapa.gob.es. s.f. Visor SIGPAC. Ministerio de Agricultura, Pesca y Alimentación. Madrid. http://sigpac.mapa.es/fega/visor/. 
[Accessed: April 7 2019]

Marco, A. \& Pollo, C.P. (1993). Análisis biogeográfico de la distribución del Lagarto verdinegro (Lacerta schreiberi, Bedriaga, 1878). Ecología 7: 457-466.

Muñoz del Viejo, A. (2005). Los anfibios y reptiles de Extremadura, In J.M. López CAballero (ed.) Conservación de la Naturaleza en Extremadura. Comunicaciones en Jornadas y Congresos. 2002-2004. Consejería de Agricultura y Medio Ambiente. Junta de Extremadura. Mérida, Spain, pp. 247-251.

Pleguezuelos, J.M., Márquez, R. \& Lizana, M. (eds.). (2002). Atlas y Libro Rojo de los Anfibios y Reptiles de España. Dirección General de Conservación de la Naturaleza - Asociación Herpetológica Española (2 $2^{\mathrm{a}}$ impresión). Madrid, Spain, pp. 587.

Salvador Milla, A. (2002). Enciclopedia Virtual de los Vertebrados Españoles [website]. CSICMuseo Nacional de Ciencias Naturales (MNCN). https://digital.csic.es/ handle /10261/131508. [Accessed: April 8 2019].

Sampaio, F.L., Harris, D.J., Perera, A. \& Salvi, D. (2014). Phylogenetic and diversity patterns of Blanus worm lizards (Squamata: Amphisbaenia): insights from mitochondrial and nuclear gene genealogies and species tree. Journal of Zoological Systematics and Evolutionary Research 53(1): 45-54.

S.I.A.R.E (Servidor de Información de Anfibios y Reptiles de España), s.f. Programa de Seguimiento de Anfibios y Reptiles de España, S.A.R.E. Asociación Herpetológica Española. Madrid, Spain. http:// siare.herpetologica.es/sare. [Accessed: April 7 2019]

Soares, C., Álvares, F., Loureiro, A., Sillero, N., Arntzen, J.W. \& Brito, J.C. (2005). Atlas of the amphibians and reptiles of PenedaGerês National Park, Portugal. Herpetozoa 18(3/4): 155-170. 